\title{
Irrigation and fungicide application on disease occurrence and yield of early and late sown sunflower
}

\author{
Ivan C. Maldaner ${ }^{1}$, Arno B. Heldwein ${ }^{2}$, Mateus P. Bortoluzzi³ ${ }^{3}$ Luis H. Loose ${ }^{3}$, \\ Dionéia D. P. Lucas $^{4} \&$ Jocélia R. da Silva \\ ${ }^{1}$ Instituto Federal Farroupilha. São Vicente do Sul, Rio Grande do Sul. E-mail: ivan_maldaner@yahoo.com.br \\ ${ }^{2}$ Departamento de Fitotecnia/Centro de Ciências Rurais/Universidade Federal de Santa Maria. Santa Maria, Rio Grande do Sul. E-mail: \\ heldweinab@smail.ufsm.br \\ ${ }^{3}$ Programa de Pós-Graduação em Agronomia/Centro de Ciências Rurais/Universidade Federal de Santa Maria. Santa Maria, Rio Grande do Sul. E-mail: \\ mateusbortoluzzi@hotmail.com (Autor correspondente); luishloose@gmail.com \\ ${ }^{4}$ Secretaria da Agricultura e Pecuária. Palmeira das Missões, Rio Grande do Sul. E-mail: dio.pitol@gmail.com \\ ${ }^{5}$ Universidade Federal de Santa Maria. Santa Maria, Rio Grande do Sul. E-mail: joceliarosa.s@gmail.com
}

\section{Key words: \\ Helianthus annuus L. \\ Alternaria helianthi \\ Septoria helianthi \\ disease forecast \\ sowing date}

\begin{abstract}
A B S T R A C T
The objective of this study was to evaluate the effect of irrigation and fungicide application on the occurrence of diseases and cypsela yield of two genotypes of sunflower. The experiments were carried out in Santa Maria-RS, during the regular season in 2007 and the late season, in 2008. Plants were sown on $04 / 09 / 2007$ and $21 / 01 / 2008$, in a completely randomized design, with four replicates. A 2 × 6 factorial scheme was used, with the sunflower genotypes Aguará 03 and Hélio 358 and six fungicide application schemes, which were determined by the FAST forecasting system, as follows: FAST 16, FAST 22 and FAST 28, without irrigation, FAST 16 IRR under irrigated condition, in addition to irrigated control (CONTROL IRR) and control (CONTROL). Disease progress was analyzed based on weekly observations of the severity of the symptoms. It was verified that irrigation increases sunflower cypsela yield in the regular season, provided that weather conditions are not favorable for the occurrence of alternaria and septoria leaf blights or that fungicides are applied. In the late season, under irrigated condition, fungicide application is necessary to control alternaria and septoria leaf blights.
\end{abstract}

\section{Palavras-chave:}

Helianthus annuus L. Alternaria helianthi Septoria helianthi previsão de doenças época de semeadura

\section{Irrigação e aplicação de fungicidas na ocorrência de doenças e na produtividade do girassol em períodos de safra e safrinha}

\section{R E S U M O}

Objetivou-se, neste trabalho, avaliar o efeito da irrigação e da aplicação de fungicidas na ocorrência de doenças e na produtividade de cipselas de dois genótipos de girassol. Os experimentos foram conduzidos em Santa Maria, RS, nos períodos de safra de 2007 e safrinha de 2008. As semeaduras foram realizadas em 04/09/2007 e 21/01/2008, sendo utilizado o delineamento inteiramente casualizado, com quatro repetições. Foi utilizado um esquema fatorial 2 × 6, constituído pelos genótipos de girassol Aguará 03 e Hélio 358 e seis esquemas de aplicação de fungicida, determinados em função do sistema de previsão FAST, os quais foram: FAST 16, FAST 22 e FAST 28, sem irrigação, FAST 16 IRR, em condição irrigada, além das testemunhas irrigada (TEST IRR) e não irrigada (TEST). O progresso da doença foi analisado com base nas observações semanais da severidade dos sintomas da doença. Verificou-se que a irrigação aumenta a produtividade de cipselas de girassol no cultivo de safra desde que as condições meteorológicas não sejam favoráveis para a ocorrência de mancha de alternaria e septoria ou que se apliquem fungicidas. $\mathrm{Na}$ safrinha em condição irrigada, a aplicação de fungicidas é necessária para o controle de mancha de alternaria e septória. 


\section{INTRODUCTION}

Currently, sunflower (Helianthus annuus L.) is among the plant species with the highest potential for the production of renewable energy in Brazil, and is used as raw material in the production of biofuels (Corrêa et al., 2008), besides being one of the five crops producing the greatest amounts of edible vegetable oil in the world (Ungaro et al., 2009).

In Brazil, the sunflower crop has mean grain production ranging from 1,300 to $1,500 \mathrm{~kg} \mathrm{ha}^{-1}$ (CONAB, 2014). However, under irrigation it has high productive potential and can exceed 4,000 kg ha-1 (Goksoy et al., 2004; Karam et al., 2007; Anastasi et al., 2010).

The cultivation of sunflower in the different productive regions in Brazil is influenced by some factors that lead to yield reduction, such as the occurrence of diseases (Leite \& Amorim, 2002; Loose et al., 2012) and periods of water deficit in the soil (Maldaner, 2012).

Supplementary irrigation, despite increasing production costs, allows minimizing losses caused by water deficit in the crops. The application of water in certain crop phases (Goksoy et al., 2004; Karam et al., 2007) or with irrigation deficit (Silva et al., 2007; Anastasi et al., 2010) contributes to increments in yield, but plants not subjected to water deficit express their maximum productive potential, provided that other factors remain unchanged.

On the other hand, the higher water availability in the soil and in plant shoots promotes the formation of a microclimate that favors the development of pathogens, depending on irrigation intensity and frequency, associated with crop management practices, genotype used, plant spacing, soil type and air temperature (Heldwein et al., 2007).

Among the diseases occurring in sunflower that cause the greatest damages, two stand out: alternaria leaf blight, caused by Alternaria helianthi (Hansf.) Tubaki and Nishihara, and septoria leaf blight, caused by Septoria helianthi Ellis and Kellerman (Leite et al., 2006; Loose et al., 2012). These diseases are favored by the climate of the state of Rio Grande do Sul, because of the frequency of occurrence of long periods of leaf wetting from the beginning of the spring until late October. On the other hand, this period is recommended for crop establishment, in order to avoid the coincidence of the period with the highest probability of water deficit and the most critical period for the crop regarding water stress (Maldaner, 2012).

Another sowing period that has stood out in the last years is the late season (from late January to late February), especially in irrigated areas, but it favors the occurrence of diseases due to the high temperature and relative air humidity in the beginning of the autumn (Loose et al., 2012).

There are no adequate technical criteria for the control of diseases in the sunflower crop, resulting in unnecessary fungicide applications in certain situations and, in others, the absence of application in periods favorable to the different pathogens. Thus, it is important to test and evaluate a disease forecasting system based on environmental conditions.

Forecasting systems have been used in Brazil for the crops of apple (Berton, 2004), potato (Trentin et al., 2009; Bosco et al., 2010; Grimm et al., 2011) and grape (Shimano \& Sentelhas, 2013), showing some advantages, such as the decrease in the risk of epidemics, reduction in the number of sprayings, higher income to the farmer and less damage to humans and the environment (Bosco et al., 2010; Grimm et al., 2011).

In the state of Rio Grande do Sul, studies related to disease control encompassing different sowing periods are important, since the sunflower crop is exposed to the variability of meteorological factors, which interfere with the water availability for the crop and the occurrence of diseases.

The objective of this study was to evaluate the effect of irrigation and fungicide application as a function of the FAST forecasting system on the occurrence of diseases and Cypsela yield of two sunflower genotypes sown in regular and late seasons, in the central region of the state of Rio Grande do Sul, Brazil.

\section{Material ANd Methods}

Two experiments were carried out in the city of Santa Maria, located in the central region of Rio Grande do Sul $\left(29^{\circ}\right.$ $43^{\prime} 23^{\prime \prime} \mathrm{S} ; 53^{\circ} 43^{\prime} 15^{\prime \prime} \mathrm{W} ; 95 \mathrm{~m}$ ), during the spring of 2007 and summer/autumn of 2008. Plants were sown on 04/09/2007 and $21 / 01 / 2008$, arranged in a completely randomized design, with four replicates. Each plot was composed of $5 \mathrm{~m}$ long plant rows, with spacing of $0.9 \mathrm{~m}$ between rows and $0.25 \mathrm{~m}$ between plants in the row, totaling 44,444 plants $\mathrm{ha}^{-1}$. The treatments constituted of a $2 \times 6$ factorial scheme, with two sunflower genotypes and six application systems, in regular and late seasons.

The sunflower genotypes Aguará 03 and Hélio 358, both with medium cycle, were used. For the application schemes, three intervals were considered between fungicide applications (FAST 16, 22, 28), all without irrigation, and only FAST 16 under irrigated condition, besides the control treatments, with and without irrigation. In order to determine the interval between the fungicide applications, the values of calculated severity (CS) were estimated by the FAST forecasting system, according to Table 1 (Madden et al., 1978).

CS ranged from 0 to 4 , depending on the mean air temperature and the leaf-wetting period, a condition considered when the relative air humidity was higher than $90 \%$, accumulating the number of hours for each day. Both were determined by thermocouple psychrometers installed in the center of the experimental area, at $1.5 \mathrm{~m}$ above soil surface, collecting data every $10 \mathrm{~min}$.

By accumulating the daily CS values, the cumulative calculated severity (CCS) was obtained, and when the CCS of the respective treatments was reached, the fungicide was applied and the counting of the accumulation restarted.

Table 1. Values of calculated severity (CS) of disease as a function of the duration of the leaf-wetting period and mean air temperature

\begin{tabular}{|c|c|c|c|c|c|}
\hline \multirow{2}{*}{$\begin{array}{c}\text { Temperature } \\
\left({ }^{\circ} \mathrm{C}\right)\end{array}$} & \multicolumn{5}{|c|}{ Calculated severity (CS) } \\
\hline & 0 & 1 & 2 & 3 & 4 \\
\hline $13.0-17.5$ & $0-6$ * & $7-15^{\star}$ & $16-20$ * & $\geq 21$ * & \\
\hline $17.6-20.5$ & $0-3$ * & $4-8$ * & $9-15$ * & $16-22$ * & $\geq 23$ * \\
\hline $20.6-25.5$ & $0-2$ * & $3-5$ * & $6-12$ * & $13-20$ * & $\geq 21 *$ \\
\hline $25.6-29.5$ & $0-3$ * & $4-8$ * & $9-15$ * & $16-22$ * & $\geq 23$ * \\
\hline
\end{tabular}

Source: Madden et al. (1978); ${ }^{*}$ Duration of the leaf-wetting period (h) 
In the regular season experiment, the systemic fungicide procymidone (Sumilex $-1.5 \mathrm{~kg} \mathrm{ha}^{-1}$ ) and the contact fungicide chlorothalonil (Daconil $-2.0 \mathrm{~kg} \mathrm{ha}^{-1}$ ) were used. In the late season experiment, the systemic fungicide pyraclostrobin + metiram (Cabrio Top - $3.0 \mathrm{~kg} \mathrm{ha}^{-1}$ ) and the contact fungicide chlorothalonil (Daconil $-2.0 \mathrm{~kg} \mathrm{ha}^{-1}$ ) were used. The products were alternately applied and, due to the residual effect of the systemic fungicides, the counting of CCS was not accumulated in the two days after the application.

In order to define the moment of irrigation, the daily water balance was calculated by the method of Thornthwaite \& Mather (1955), described by Pereira et al. (1997), considering water storage capacity of $65 \mathrm{~mm}$ until the depth of $0.5 \mathrm{~m}$ (Cardoso, 2005).

The meteorological data were obtained from an automatic weather station (Davis) and an electronic data-acquisition system (data logger) installed in the center of the experimental area. Sprinklers (Agrojet P5 RB) with $1 / 2$ ' thread, flow rate of 200 $\mathrm{L} \mathrm{h}^{-1}$ and spacing of $5 \times 4.5 \mathrm{~m}$ were used.

The widths of each leaf of one plant per plot were weekly measured and the leaf area was estimated by Eq. 1 (Maldaner et al., 2009). Then, the leaf area index (LAI) was determined.

$$
\mathrm{LA}=1.7582 \times(\mathrm{W})^{1.7069}
$$

where:

$$
\begin{aligned}
& \text { LA - leaf area, } \mathrm{cm}^{2} \text {; and } \\
& \text { W }- \text { maximum leaf width, perpendicular to the midrib, } \mathrm{cm} .
\end{aligned}
$$

The progress of the diseases was observed every seven days, by evaluating the severity of the symptoms and using the diagrammatic scale described by Leite \& Amorim (2002), in three plants per plot considering three height levels (upper, middle, lower). The mean severity of the three levels was calculated and the analysed values were corresponded to the mean of the three plants of each plot.

For the statistical evaluation of the observed severity (OS), the values of severity 93 days after emergence (DAE) for the regular season and $84 \mathrm{DAE}$ for the late season were considered. With the OS mean values, the area under the disease progress curve (AUDPC) was calculated from the integration of the disease progress curves and the healthy leaf area duration (HLAD), according to Eqs. 2 and 3, described by Campbell \& Madden (1990). High values of HLAD and lower values of OS and AUDPC corresponded to smaller damages caused by the disease.

$$
\text { AUDPC }=\sum_{i=1}^{n-1}\left(\frac{\mathrm{OS}_{\mathrm{i}}+\mathrm{OS}_{\mathrm{i}+1}}{2}\right)\left(\mathrm{t}_{\mathrm{i}+1}-\mathrm{t}_{\mathrm{i}}\right)
$$

$$
\mathrm{HLAD}=\sum_{\mathrm{i}-1}^{\mathrm{n}-1}\left\{0,5\left[\mathrm{LAI}_{\mathrm{i}}\left(1-\mathrm{OS}_{\mathrm{i}}\right)+\mathrm{LAI}_{\mathrm{i}+1}\left(1-\mathrm{OS}_{\mathrm{i}+1}\right)\right]\right\}\left(\mathrm{t}_{\mathrm{i}+1}-\mathrm{t}_{\mathrm{i}}\right)
$$

where:

AUDPC - area under the disease progress curve;

$\mathrm{n}$ - number of evaluations;

$\mathrm{OS}_{\mathrm{i}}$ and $\mathrm{OS}_{\mathrm{i}+1}$ - observed severity of alternaria and/or septoria leaf blight, for the times i and $i+1, \%$;

$t_{i+1}-t_{i}$ - time interval between consecutive evaluations of severity, days;
HLAD - healthy leaf area duration; and

$\mathrm{LAI}_{\mathrm{i}}$ - leaf area index for the time $\mathrm{i}$.

In both experiments, Alternaria helianthi and Septoria helianthi were not artificially inoculated; the infection occurred naturally. The harvests were performed on 08/01/2008 for the regular season and on 29/04/2008 for the late season. Then, Cypsela yield (AY) and 1000-Cypsela weight (TAW) were determined.

The results obtained in the different treatments were subjected to the analysis of variance by the $\mathrm{F}$ test and the means were compared using the Scott Knott test at 0.05 probability level. For the statistical analysis, OS data were transformed into $\arcsin (\mathrm{x} / 100)^{-0.5}$.

\section{Results AND Discussion}

In the regular season experiment, four irrigations (36, 24, 40 and $18 \mathrm{~mm}$ ) were performed throughout the sunflower cycle; the first one at 62 DAE between the R1and R5.1 stages (Figure 1A).
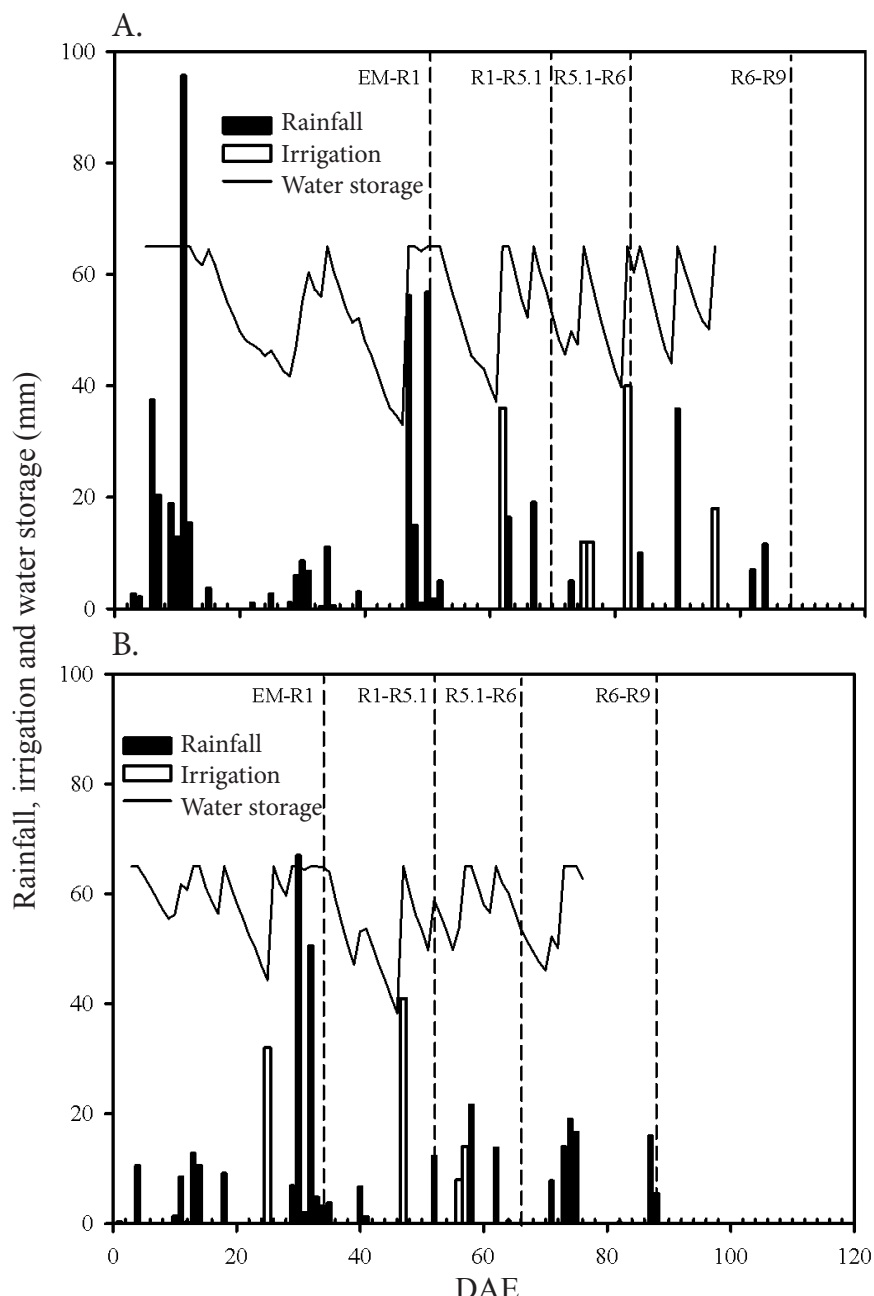

Figure 1. Complementary irrigations performed as a function of soil water storage and the rainfall occurred in the regular season in 2007 (A) and late season in 2008 (B), as a function of the days after emergence (DAE), during the sunflower development stages: from emergence to flowerbud appearance (EM-R1); from flowerbud appearance to petal opening (R1R5.1); from petal opening to petal wilting (R5.1-R6); from petal wilting to physiological maturation (R6-R9) 
In the late season experiment, there were also four irrigations $(25,41,8$ and $14 \mathrm{~mm})$, and the first one was performed in the crop vegetative stage, at $26 \mathrm{DAE}$ (Figure 1B).

In the analysis of variance for the experiments of regular and late seasons, and considering two factors, genotype and fungicide application scheme, there was no significant interaction for all the evaluated variables. The genotype Hélio 358 showed higher HLAD and OS in comparison to Aguará 03, in the regular season, not differing for the variables TAW and AY (Table 2). In the late season, the genotype Hélio 358 showed higher TAW, but it did not correspond to higher Cypsela yield compared with the genotype Aguará 03, which in turn showed higher HLAD and lower OS.

Considering the factor application scheme in the regular season experiment, the treatments with fungicide application showed higher HLAD and lower AUDPC and OS (Table 2). In spite of that, the irrigated treatments showed higher AY, highlighting the preponderant effect of irrigation, in relation to the damage caused by diseases, which can also be verified by the lack of significant difference between the treatments FAST 16 IRR and CONTROL IRR.

Still in the regular season experiment, the treatment CONTROL IRR showed higher OS in comparison to the CONTROL; however, it reached a higher AY (Table 2). These results indicate that, despite causing an increase in AY, irrigation in sunflower also caused an increase in the symptoms of alternaria and septoria leaf blights, probably due to the longer period with free water on the leaves during irrigation events, which can have favored the infection of plants by the pathogens that cause these diseases.

Table 2. Healthy leaf area duration (HLAD), area under the disease progress curve (AUDPC), observed severity (OS), 1000-Cypsela weight (TAW) and Cypsela yield (AY), at 93 days after emergence (DAE) in the regular season and $84 \mathrm{DAE}$ in the late season, for the factors genotype and fungicide application scheme

\begin{tabular}{|c|c|c|c|c|c|}
\hline & HLAD & AUDPC & OS & $\begin{array}{c}\text { TAW } \\
(\mathrm{g})\end{array}$ & $\begin{array}{c}\text { AY } \\
\left(\mathrm{kg} \mathrm{ha}^{-1}\right)\end{array}$ \\
\hline \multicolumn{6}{|c|}{ Genotype (Regular season) } \\
\hline Hélio 358 & $180.97 \mathrm{a}$ & a & $a$ & $1.15 \mathrm{a}$ & $3782 \mathrm{a}$ \\
\hline Aguar & & & & $2.32 \mathrm{a}$ & $3711 \mathrm{a}$ \\
\hline \multicolumn{6}{|c|}{ Application scheme (Regular season) } \\
\hline CONTROL IRR & $152.24 \mathrm{~b}$ & $1227.60 \mathrm{a}$ & $34.64 \mathrm{a}$ & $58.75 \mathrm{a}$ & 4093 a \\
\hline CONT & & & $30.15 b$ & $63.06 \mathrm{a}$ & $3612 b$ \\
\hline FAST & & & $26.03 \mathrm{c}$ & $60.65 \mathrm{a}$ & $4112 \mathrm{a}$ \\
\hline FAST & a & & $24.04 \mathrm{C}$ & $63.64 \mathrm{a}$ & $3465 b$ \\
\hline FAST & $a$ & $\mathrm{~b}$ & $25.36 \mathrm{c}$ & $62.70 \mathrm{a}$ & $3566 \mathrm{~b}$ \\
\hline FAST 28 & $158.70 \mathrm{a}$ & & & $61.61 \mathrm{a}$ & $3629 \mathrm{~b}$ \\
\hline \multicolumn{6}{|c|}{ Genotype (Late season) } \\
\hline Hélio 358 & $112.57 b$ & $7 \mathrm{a}$ & $53.17 \mathrm{a}$ & $54.67 \mathrm{a}$ & $2285 \mathrm{a}$ \\
\hline Aguará 03 & $124.89 \mathrm{a}$ & $3 a$ & $44.53 \mathrm{~b}$ & $48.67 \mathrm{~b}$ & $2196 \mathrm{a}$ \\
\hline \multicolumn{6}{|c|}{ Application scheme (Late season) } \\
\hline CONT & $112.43 b$ & $7 \mathrm{a}$ & a & $46.20 \mathrm{~b}$ & $1842 b$ \\
\hline & & & a & $3 \mathrm{a}$ & $2136 \mathrm{a}$ \\
\hline & & & a & $2.61 \mathrm{a}$ & $2233 a$ \\
\hline Ff & & & 42. & $4.28 \mathrm{a}$ & $2357 \mathrm{a}$ \\
\hline & & & $3 \mathrm{~b}$ & $2.32 \mathrm{a}$ & $2431 \mathrm{a}$ \\
\hline FAST 28 & $122.38 \mathrm{a}$ & $1473.16 \mathrm{c}$ & $41.54 \mathrm{~b}$ & $54.21 \mathrm{a}$ & $2446 \mathrm{a}$ \\
\hline \multicolumn{6}{|c|}{$\begin{array}{l}\text { Means followed by the same letter in the column, for each factor, do not differ by Scott-Knott } \\
\text { test at } 0.05 \text { probability level; FAST } 16, \text { FAST } 22 \text {, FAST } 28 \text { - Treatments without irrigation and } \\
\text { with fungicide application predicted by the FAST forecasting system with } 16,22 \text { and } 28 \text { severity } \\
\text { values, respectively; FAST } 16 \text { IRR - Treatment with irrigation and with fungicide application } \\
\text { predicted by the FAST forecasting system, with } 16 \text { severity values; CONTROL = control treatment } \\
\text { without irrigation or fungicide application; CONTROL IRR - control treatment with irrigation and } \\
\text { without fungicide application }\end{array}$} \\
\hline
\end{tabular}

Based on the variables AUDPC and OS, the treatments with fungicide application were efficient at minimizing the symptoms of the diseases in the regular season experiment, but were not statistically different. In total, three fungicide applications were performed throughout the sunflower cycle, except for the treatment FAST 28, in which only two applications were performed; in this case, the treatment FAST 28 could be recommended for the control of diseases in sunflower, since there was an economy of $33 \%$ in the use of fungicide, compared with the treatment FAST 16, resulting in lower production costs.

It can also be inferred that the application of fungicides before the R1 stage is unnecessary in years when the incidence of diseases is late and with low severity values, as occurred in the regular season experiment, considering that the damage caused by the diseases did not impose significant yield reduction, in both irrigated and non-irrigated treatments.

In the late season experiment, the first disease symptoms were verified $23 \mathrm{DAE}$, before the regular season experiment, in which the first symptoms were observed $35 \mathrm{DAE}$. The treatment CONTROL IRR showed the lowest TAW, which was also reflected in lower AY (Table 2). This low yield can be explained by the probable negative effect of the irrigation performed during the crop vegetative phase, contributing to high AUDPC and low HLAD, although there was no difference for these variables in the CONTROL.

The early infection caused high disease severity at the beginning of the reproductive phase. Leite et al. (2006) observed yields lower than $500 \mathrm{~kg} \mathrm{ha}^{-1}$ when the severity was higher than $10 \%$ in the R3 stage, showing that this is a critical phase of the crop cycle. These results show the importance of fungicide applications under such conditions.

AY and TAW were lower in the late season experiment, compared with the regular season, in the evaluated treatments. OS and AUDPC were higher and HLAD was lower in the late season, showing greater damage in the sunflower plants by the diseases during this period (Table 2).

The lower yield and the higher severity of the diseases can have occurred due to the micrometeorological conditions of the canopy, especially because air temperature and leaf wetting were more favorable to the development of diseases in the second sowing period. These results corroborate the ones of Loose et al. (2012), who verified higher occurrence of diseases in the sowings performed in January and February, and by Leite et al. (2006), who found higher yield and lower severity of alternaria leaf blight for the sowing dates in October and November, in Londrina-PR.

For the application scheme FAST 16 IRR, the cypsela yield was $76 \%$ higher in the regular season experiment, compared with the late season, which can also be explained by the higher leaf area index (LAI) and longer period of grain filling. Associated with this, there was no abrupt reduction, as occurred in LAI for the late season, which can have damaged the plants in the phase of grain filling, considering that the cypsela filling rate is affected by the photosynthetic capacity of the plant during the mentioned period (Andrade \& Ferreiro, 1996).

The correlation analysis between plot yield and the variables HLAD and AUDPC did not show any tendency in the regressions for the regular season, with a low correlation $\left(\mathrm{R}^{2}<0.09\right)$. In the 
late season, the equations obtained for the genotype Hélio 358 were $y=-0.4849 x+3145.1\left(R^{2}=0.10\right)$ and $y=30.44 x-1105$ $\left(\mathrm{R}^{2}=0.17\right)$, for AUDPC and HLAD, respectively. The highest $\mathrm{R}^{2}$ value obtained was 0.42 for the genotype Aguará 03 for both analysed variables, with the equations $y=-0.9824 x+3807.2$ for HLAD and $y=43.401 x-3192.1$ for AUDPC. Leite et al. (2006) did not find good adjustment for the variable HLAD for both exponential and linear regression models, but obtained good relation between yield and AUDPC, in two of the three years studied.

Although the obtained $\mathrm{R}^{2}$ values were not high, a positive linear relation was found between the variables HLAD and yield, and a negative relation between AUDPC and yield, which was also observed by Trentin et al. (2009) and Bosco et al. (2010) for the late blight in potato, and by Allen et al. (1981) and Leite et al. (2006), for the alternaria leaf blight in sunflower.

The forecasting system and the fungicides used were efficient at predicting and partially controlling the diseases in the late season experiment, considering that HLAD was higher, AUDPC was lower and AY was higher in the treatment FAST 16 IRR, when compared with the CONTROL IRR (Table 2). Thus, it can be inferred that irrigation can be harmful if performed without the application of fungicides in sunflower sown in the late season.

In the non-irrigated treatments, HLAD was higher and OS and AUDPC were lower in the treatments with fungicide application in comparison to the CONTROL. In addition, the chemical control resulted in a yield increase of at least $120 \mathrm{~kg}$ $\mathrm{ha}^{-1}$, although without significant difference, which can make viable the application of fungicides.

In the regular season, when the meteorological conditions were more favorable to sunflower growth and development, irrigation is a factor that promotes yield increase, especially in periods with strong water deficit in the soil.

On the other hand, the cultivation of sunflower in the late season should be carefully adopted in years with the occurrence of the phenomenon "El Niño" or with the use of irrigation (Loose et al., 2010; 2012). Under these conditions, there is an increase in the leaf-wetting period, which causes losses when combined with air temperatures favorable to infection and development of alternaria and septoria leaf blights, as reported by Santos et al. (2012), in a study conducted in Tocantins, who found lower yields in late periods due to the high infection rate by alternaria leaf blight, mainly due to the high rainfall occurring at the beginning of the reproductive phase.

\section{Conclusions}

1. The occurrence of diseases in sunflower can be predicted using meteorological elements, but adjustments are necessary to define the most adequate criteria.

2. Irrigation increases cypsela yield in sunflower sown in the regular season, provided that the meteorological conditions are not favorable for the occurrence of alternaria and septoria leaf blights, or that fungicides are applied to control these diseases.

3. In the late season, under irrigation, fungicide application is essential to control alternaria and septoria leaf blights in sunflower.

\section{Literature Cited}

Allen, S. J.; Kochman, J. K.; Brown, J. F. Losses in sunflowers yield caused by Alternaria helianthi in southern Queensland. Australian Journal for Experimental Agriculture and Animal Husbandry, v.21, p.98-100, 1981. http://dx.doi.org/10.1071/EA9810098

Anastasi, U.; Santonoceto, C.; Giuffre, A. M.; Sortino, O.; Abbate, V. Yield performance and grain lipid composition of standard and oleic sunflower as affected by water supply. Field Crops Research, v.119, p.145-153, 2010. http://dx.doi.org/10.1016/j.fcr.2010.07.001

Andrade, F. H.; Ferreiro, M. Reproductive growth of maize, sunflower and soybean at different source levels during grain filling. Field Crops Research, v.48, p.155-165, 1996. http://dx.doi.org/10.1016/ S0378-4290(96)01017-9

Berton, O. Previsão e controle da sarna da macieira. In: Reis, E. M. Previsão de doenças de plantas. Passo Fundo: UPF, 2004. Cap.7, p.289-315.

Bosco, L.; Heldwein, A. B.; Blume, E.; Trentin, G.; Grimm, E. L.; Lucas, D. D. P.; Loose, L. H.; Radons, S. Z. Sistemas de previsão de requeima em cultivos de batata em Santa Maria, RS. Bragantia, v.69, p.649660, 2010. http://dx.doi.org/10.1590/S0006-87052010000300017

Campbell, C. L.; Madden, L. V. Forecasting plant diseases. In: Campbell, C. L.; Madden, L. V. Introduction to plant disease epidemiology. New York: John Wiley \& Sons, 1990. Cap.15, p.423-452.

Cardoso, C. D. V. Probabilidade de ocorrência de deficiência hídrica nos solos da região central do Estado do Rio Grande do Sul. Santa Maria: UFSM, 2005. 165p. Tese Doutorado

CONAB - Companhia Nacional de Abastecimento. Série histórica de produtividade: safras 1976/77 a 2013/2014. Brasília, 2014. http:// www.conab.gov.br/conteudos.php?a=1252\&t=2. 28 Jan. 2014.

Corrêa, I. M.; Maziero, J. V. G.; Úngaro, M. R.; Bernardi, J. A.; Storino, M. Desempenho de motor diesel com misturas de biodiesel de óleo de girassol. Ciência e Agrotecnologia, v.32, p.923-928, 2008. http:// dx.doi.org/10.1590/S1413-70542008000300033

Goksoy, A. T.; Demir, A. O.; Turan, Z. M.; Dagustu, N. Responses of sunflower to full and limited irrigation at different growth stages. Field Crops Research, v.87, p.167-178, 2004. http://dx.doi. org/10.1016/j.fcr.2003.11.004

Grimm, E. L.; Heldwein, A. B; Radons, S. Z.; Maldaner, I. C.; Trentin, G.; Bosco, L. C. Produtividade da batata em função da irrigação e do controle químico da requeima. Revista Brasileira de Engenharia Agrícola e Ambiental, v.15, p.125-130, 2011. http://dx.doi. org/10.1590/S1415-43662011000200003

Heldwein, A. B.; Conterato, I. F.; Trentin, G.; Nied, A. H. Princípio para implementar alertas agrometeorológicos e fitossanitários. In: Carlesso, R.; Petry, M. T.; Rosa, G. M. da; Heldwein, A. B. Usos e benefício da coleta automática de dados meteorológicos na agricultura. Santa Maria: UFSM, 2007. Cap.5, p.115-134.

Karam, F.; Lahoud, R.; Masaad, R.; Kabalan, R.; Breidi, J.; Chalita, C.; Rouphael, Y. Evapotranspiration, seed yield and water use efûciency of drip irrigated sunflower under full and deficit irrigation conditions. Agricultural Water Management, v.90, p.213-223, 2007. http://dx.doi.org/10.1016/j.agwat.2007.03.009

Leite, R. M. V. B. C.; Amorim, L. Elaboração e validação de escala diagramática para mancha de Alternaria em girassol. Summa Phytopathologica, v.28, p.14-19, 2002. 
Leite, R. M. V. B. C.; Amorim, L.; Bergamin Filho, A. Relationships of disease and leaf area variables with yield in the Alternaria helianthisunflower pathosystem. Plant Pathology, v.55, p.73-81. 2006. http:// dx.doi.org/10.1111/j.1365-3059.2005.01313.x

Loose, L. H.; Heldwein, A. B.; Maldaner, I. C.; Lucas, D. D. P.; Hinnah, F. D.; Bortoluzzi, M. P. Severidade de ocorrência das manchas de alternária e septoriose em girassol semeado em diferentes épocas no Rio Grande do Sul. Bragantia, v.71, p.282-289, 2012. http://dx.doi. org/10.1590/S0006-87052012005000012

Loose, L. H.; Long, M. E. F.; Carnelos, D.; Murphy, G. M. Variabilidade dos rendimentos de girassol na Argentina em função da variabilidade climática interanual. Revista de la Facultad de Agronomia - UBA, v.30, p.169-178, 2010.

Madden, L. V.; Pennypacker, S. P.; Macnab, A. A. Fast, a forecast system for Alternaria solani on tomato. Phytopathology, v.68, p.1354-1358, 1978. http://dx.doi.org/10.1094/Phyto-68-1354

Maldaner, I. C. Probabilidade de ocorrência de deficiência hídrica na cultura do girassol na região central do Rio Grande do Sul. Santa Maria: UFSM, 2012. 141p. Tese Doutorado

Maldaner, I. C.; Heldwein, A. B.; Loose, L. H.; Lucas, D. D. P.; Guse, F. I.; Bortoluzzi; M. P. Modelos de determinação não-destrutiva da área foliar em girassol. Ciência Rural, v.39, p.1356-1361, 2009. http:// dx.doi.org/10.1590/S0103-84782009000500008

Pereira, A. R.; Villa-Nova, N. A.; Sediyama, G. C. Evapo(transpi)ração. Piracicaba: FEALQ, 1997. 183p.
Santos, E. R.; Barros, H. B.; Capone, A.; Ferraz E. C.; Fidelis, R. R. Efeito de épocas de semeadura sobre cultivares de girassol, no Sul do Estado do Tocantins. Revista Ciência Agronômica, v.43, p.199-206, 2012. http://dx.doi.org/10.1590/S180666902012000100025

Shimano, I. S. H.; Sentelhas, P. C. Risco climático para ocorrência de doenças fúngicas da videira no Sul e Sudeste do Brasil. Revista Ciência Agronômica, v.44, p.527-537, 2013. http://dx.doi. org/10.1590/S1806-66902013000300015

Silva, M. L. O.; Faria, M. A.; Morais, A. R.; Andrade, G. P.; Lima, E. M. C. Crescimento e produtividade do girassol cultivado na entressafra com diferentes lâminas de água. Revista Brasileira de Engenharia Agrícola e Ambiental, v.11, p.482-488, 2007. http:// dx.doi.org/10.1590/S1415-43662007000500006

Thornthwaite, C. W.; Mather, J. R. The water balance. Publications in Climatology. New Jersey: Drexel Institute of Technology, 1955.104p.

Trentin, G.; Heldwein, A. B.; Streck, L.; Maass, G. F.; Radons, S. Z.; Trentin, R. Controle da requeima em batata cv. 'Asterix' como base para modelos de previsão da doença. Ciência Rural, v.39, p.393-399, 2009. http://dx.doi.org/10.1590/S010384782009000200012

Ungaro, M. R. G.; Castro, C. D.; Farias, J. R. B.; Barni, N. A.; Ramos, N. P.; Sentelhas, P. C. Girassol. In: Monteiro, J. E. B. A. (org.). Agrometeorologia dos cultivos: o fator meteorológico na produção agrícola. Brasília: INMET, 2009. p.205-221. 